\title{
BIOLOGICAL PRETREATMENT OF WASTE FROM THE LEATHER INDUSTRY TO OBTAIN BIOGAS THROUGH ANAEROBIC CO-DIGESTION PROCESSES - A REVIEW
}

\author{
MARIANA FERDES ${ }^{1}$, ROXANA RODICA CONSTANTINESCU ${ }^{2}$ \\ ${ }^{1}$ University Politehnica Bucharest, Romania, marianaferdes@yahoo.com \\ ${ }^{2}$ Leather and Footwear Research Institute, Bucharest, Romania, rodica.roxana@yahoo.com
}

\begin{abstract}
The leather industry produces a relatively high amount of hard degradable waste, with a negative impact on the environment. This waste usually contains two major categories of residues, namely animal fat and residues containing mostly proteins, suitable for biogas conversion. Obtaining biogas from leather waste by co-digestion with vegetable waste can be a sustainable and ecofriendly alternative to conventional energy from fuels. Anaerobic co-digestion is now considered to reduce waste from various sources and turn it into energy, generating in addition a digestate used as fertilizer in agriculture. This waste is relatively resistant to transformation into an easily fermentable substrate for anaerobic digestion to produce biogas. Thus, the methane yield can be significantly improved by biological treatments with enzymes and enzyme complexes, with microorganisms selected and used as inoculum or by mixed methods, which include other physical or chemical treatments. This paper aims to show the main methods of biological treatment of leather industry waste, in order to increase the yield of biogas by co-digestion with plant materials.
\end{abstract}

Keywords: leather industry, waste, biogas, proteases, lipases, microorganisms

\section{INTRODUCTION}

The global reduction of conventional energy resources, as well as restrictive legislation on the level of environmental pollution, have created premises for the identification and exploitation of new energy sources, economic and non-polluting.

The anaerobic fermentation process is considered to be a key technology for the sustainable use of biomass consisting of the organic fraction of industrial waste, municipal solid waste, animal manure, plant debris, aquatic biomass, but also energy crops suitable for this process (Nallathambi Gunaseelan, 1997). Recently, the anaerobic fermentation process has gained special attention due to environmental protection by reducing greenhouse gas emissions, and generation of biogas, a promising source of renewable energy. The benefits of anaerobic fermentation technology are also reflected in the stability and agronomic quality of the fertilizer obtained. This method of treatment is in accordance with the provisions of the European Union, which involve the reduction and recovery of waste, as well as the promotion of clean technologies (Scano et al., 2014).

Anaerobic fermentation is a process of decomposition of the organic substrate in the presence of several species of bacteria, under controlled environmental conditions, in the absence of oxygen (Chen and Neibling, 2014; Zupancic and Grlic, 2012).

The composition of the biogas resulting from the anaerobic fermentation process varies depending on the raw material used, but also on the fermentation conditions. In general, biogas consists of two main components, methane $\left(\mathrm{CH}_{4}\right)$ and carbon dioxide $\left(\mathrm{CO}_{2}\right)$, along with small amounts of hydrogen $\left(\mathrm{H}_{2}\right)$, hydrogen sulfide $\left(\mathrm{H}_{2} \mathrm{~S}\right)$, nitrogen $\left(\mathrm{N}_{2}\right)$, ammonia $\left(\mathrm{NH}_{3}\right)$, oxygen $\left(\mathrm{O}_{2}\right)$ and water vapor (Valenti et al., 2016).

\section{Phases of the Anaerobic Fermentation Process}

Biogas production by anaerobic fermentation is a complex process consisting of 4 phases, which are the following: hydrolysis, acidogenesis, acetogenesis and 
methanogenesis, produced under the action of several species of bacteria (Gould, 2014; Khalid et al., 2011).

Bacteria degrade the substrate through enzymes that are macromolecules of protein origin, acting as biocatalysts, with the help of which living cells can produce complex reactions in a short time. By catalyzing biochemical reactions, they play a key role in the biosynthesis and degradation of living matter, occurring in all animal, plant and microorganisms. Bacterial enzymes are exo or endo enzymes that greatly accelerate the rate of biochemical reactions (Gerardi, 2003).

\section{Hydrolysis}

In the first stage, the hydrolysis, fermentative bacteria transform insoluble organic matter into sugars, amino acids and fatty acids. At this stage, microorganisms such as Clostridium, Micrococcus, Bacteroides, Butyrivibrio, Fusobacterium, Selenomonas and Streptococcus act (Cirne et al., 2007) and produce hydrolysis enzymes involved in the degradation of substrate.

\section{Protein Hydrolysis}

Proteins are polymers of amino acids, joined by peptide bonds, whose hydrolysis is mediated by extracellular proteases that give rise to polypeptides and free amino acids (Karlsson et al., 2014). During the hydrolysis step of anaerobic digestion, proteins are first converted to individual amino acids or peptides with short amino acid chains. During the fermentation stage, the breakdown of amino acids takes place, and the amino groups are released as ammonia $\left(\mathrm{NH}_{3}\right)$ or ammonium $\left(\mathrm{NH}_{4}{ }^{+}\right)$(Schnürer and Jarvis, 2010). During the protein degradation period, ammonia $\left(\mathrm{NH}_{3}\right)$ is released into the liquid part of the substrate in the fermenter, and can inhibit the fermentation process.

Organic waste contains proteins and fats, which are rich in energy and produce a relatively large amount of methane in biogas. Substrates with high protein and fat content, generally come from the leather and food industries, being useful in biogas production because they have high methanogenic potential (up to 500-600 1/ kg volatile solids) (Hejnfelt and Angelidaki, 2009).

The main materials from the leather industry are characterized by a high content of proteins and lipids, derived from leather processing.

The leather-making process generates substantial quantities of solid waste before and after the tanning stage, which are a potential source in the anaerobic digestion of biogas process (Agustini et al., 2018). The main solid residues are hide and leather shavings (Piccin et al., 2016) and sludge from wastewater treatment plants (Mella et al., 2016). Some important characteristics of these residues include the high organic load and the difficulty of degradation of recalcitrant and poorly biodegradable compounds (Mannucci et al., 2010).

The inhibition of the bioprocess of wastewaters treatment in the wastewater treatment plants, due to the presence of chromium has been demonstrated for concentrations of $140 \mathrm{mg} / \mathrm{L}$, which cause a $50 \%$ reduction of bacterial activity. The other tanning agent class, which is popularly used, is based on vegetable tannins, which are extracted from plants. (Kalyanaraman et al., 2015). The toxicity of tannins can be associated with several mechanisms such as enzyme inhibition, substrate deprivation and loss of metal ions (Bhoite and Murthy, 2015). 
Hydrolysis of Fats

The lipids represented by fats, oils and / or greases are mainly glycerol esters with three long-chain fatty acids, which form triglycerides. Lipids are part of various waste streams: leather and food industry, domestic sewage, industrial effluents, food processing, wool washing, food oil manufacturing (Karlsson et al., 2014).

In general, fats consist of glycerol and various fatty acids released by biodegradation. The enzymes that break down fats are the lipases, which are produced by aerobic or facultative aerobic microorganisms.

\section{Acidogenesis}

Acidogenesis is the fastest stage in the process of anaerobic conversion of complex organic matter, being also called the stage of acid fermentation. The monomers resulting from the hydrolysis phase are degraded by various anaerobic and optionally anaerobic bacteria into organic acids (acetic, propionic and butyric acid), volatile fatty acids, alcohols, hydrogen $\left(\mathrm{H}_{2}\right)$, carbon dioxide $\left(\mathrm{CO}_{2}\right)$ and ammonia (Kalyuzhnyi et al., 2000).

\section{Acetogenesis}

In the third phase, acetogenic bacteria convert volatile fatty acids and alcohols into hydrogen $\left(\mathrm{H}_{2}\right)$, carbon dioxide $\left(\mathrm{CO}_{2}\right)$ and acetic acid, which is the substrate for the last stage of the process, methanogenesis (Yi et al., 2014).

\section{Methanogenesis}

In the last phase of the anaerobic fermentation process, methanogenesis, are involved the methanogenic bacteria, which are very sensitive to changes in environmental factors, such as $\mathrm{pH}$ and temperature. Under these conditions, methanogenic bacteria are considered to be the factor that limits the rate of the anaerobic fermentation process (Chen et al., 2008). During this stage, the microorganisms convert the hydrogen and acetic acid previously formed into methane $\left(\mathrm{CH}_{4}\right)$ and carbon dioxide $\left(\mathrm{CO}_{2}\right)$.

Obtaining biogas from leather waste by co-digestion with vegetable waste can be a sustainable and eco-friendly alternative to conventional energy from fuels. Anaerobic co-digestion is now considered to reduce waste from various sources and turn it into energy, generating in addition a digestate used as fertilizer in agriculture.

\section{Microbial Proteases}

Microbial proteases are synthesized from the exponential growth phase and are primary metabolites of major importance for the metabolic functions of the cell. Both bacteria and fungi can produce proteases, depending on the species and environmental conditions.

Keratinolytic protease is a new generation of proteolytic enzymes with the ability to degrade recalcitrant keratin proteins like leather, feathers, horn, hooves, nails, hairs etc as well as potentially de- grade normal proteins (Brandelli, 2008). These keratinous wastes are difficult to degrade due to the dense polypeptide tightly packed by several hydrogen bonds and hydrophobic interactions. In addition,s trong disulfide cross-linking of protein chains confers high mechanical stability and resistance to proteolytic degradation of keratins by common proteases (figure 1) (Parry and North, 1998; Kreplak et al., 2004). Their unique property to degrade tough rigid protein structure has 


\section{Biological Pretreatment of Waste from the Leather Industry to Obtain Biogas through Anaerobic Co-Digestion Processes - A Review}

made them attractive biocatalysts in industrial areas dealing with those substrates like dehairing of skins and hides, detergent additives (Gupta and Ramnani, 2006). However, many researchers found that not only is keratinase a superior enzyme among those of the protease world but also the fermented feathers hydrolysate produced by keratinase gives a rich low cost substrate for biogas production and has an important potentiality to economic important plants (Gurav and Jadhav, 2013; Paul et al., 2013). A recent study found that fermented chicken feathers hydrolysate by Paenibacillus woosongensis TKB2 is a potential anti Staphylococcus agent (Paul et al., 2015).

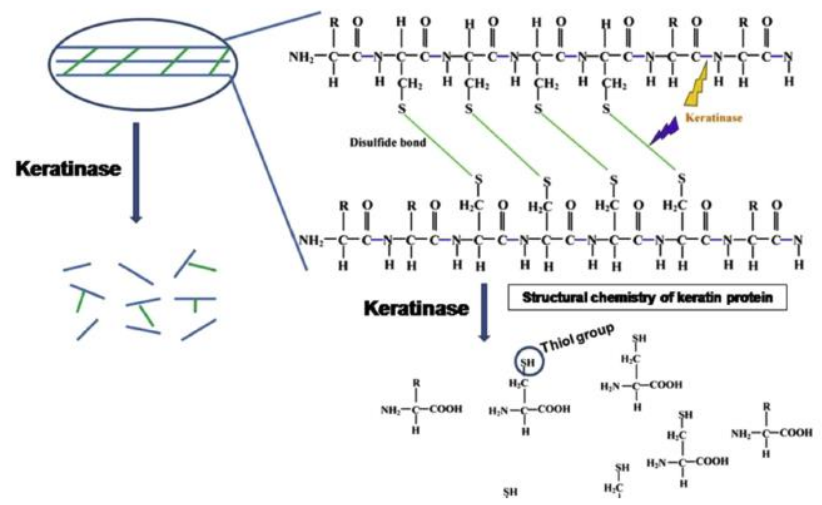

Figure 1. Mode of action of keratinolytic protease enzyme (Paul et al., 2016)

The characteristics of some bacterial proteases are shown in Table 1.

Table 1. Bacterial proteases (Paul et al., 2016)

\begin{tabular}{llll}
\hline \multicolumn{1}{c}{ Microorganism } & $\begin{array}{c}\text { Optimum } \\
\mathrm{pH}\end{array}$ & $\begin{array}{c}\text { Optimum } \\
\text { temperature, }{ }^{\circ} \mathrm{C}\end{array}$ & Type \\
\hline Bacillus sp. strain 221 & - & - & - \\
Bacillus sp. strain DZ100 & 12.5 & 85 & Serine Protease \\
Serratia marcescens P3 & 6.5 & $40-45$ & Metalloprotease \\
Chryseobacterium gleum & 8 & 30 & Metalloprotease \\
Bacillus sp. P7 & 9 & 55 & Serine Protease \\
Streptomyces sp. strain AB1 & 11.5 & 75 & Serine Protease \\
Bacillus subtilis strain RM-01 & 9 & 45 & Serine Protease \\
Bacillus licheniformis ER-15 & 11 & 70 & Serine Protease \\
Bacillus pumilus ZED17 & 8 & 40 & - \\
Bacillus mojavensis A21 & $8-11$ & 60 & Serine Protease \\
Pseudomonas aeruginosa C11 & 7.5 & 50 & Metalloprotease \\
\hline
\end{tabular}

An important feature of waste from the textile industry is the presence of various toxic components for microorganisms, which can inhibit both the multiplication of microbial cells and the entire process of anaerobic digestion.

The main form of solid tanned waste, constituting about $10 \%$ of the total weight of raw materials processed, is chromium and protein in the form of "chrome shavings" (CRS), which are small, thin pieces of leather generated during the hide shaving operation and represent high value protein-based waste (Pillai and Archana, 2012; John Sundar et al., 2011) Enzymatic treatment of CRS has been used to recover chromium 
and protein from CRS. Alkaline proteases like alcalase and combination of trypsin and esterase are used in the preparation of soluble collagen hydrolysate from CRS called chrome cake (Kupec et al., 2002).

Microbial growth on CRS necessitates the capacity of the strain to grow in highly concentrated chromium containing environment (Thacker et al., 2006). Some research (Katsifas et al., 2004) reported a chromium tolerant strain of Aspergillus carbonarius that degrades CRS in solid state fermentation process and they propose it as a useful tool in the tanning industries for the management of CRS and recovery of valuable Cr.

In other studies, the use of the keratinolytic isolate Bacillus subtilis P13 which is able to grow in alkali-free CRS, offers a promising prospect for the biodegradation of CRS along with recovery of chromium from the liquefied waste and additionally generates a valuable byproduct that can be used in biogas production (Pillai and Archana, 2012).

\section{CONCLUSION}

The leather-making process generates substantial quantities of solid waste before and after the tanning stage, which are a potential source of substrate for biogas production, in the co-digestion process.

The main solid residues are hide and leather shavings and sludge from wastewater treatment plants. Some important characteristics of these residues include the high organic load and the difficulty of degradation of recalcitrant and poorly biodegradable compounds.

The most important in the biological treatment are enzyme-producing microorganisms, able to synthesize proteases and lipases.

The methane yield can be significantly improved by biological treatments with enzymes and enzyme complexes, with microorganisms selected and used as inoculum or by mixed methods, which include other physical or chemical treatments.

\section{REFERENCES}

Agustini, C.B., Spier, F., da Costa, M. and Gutterres, M. (2018), "Biogas production for anaerobic codigestion of tannery solid wastes under presence and absence of the tanning agent", Resources, Conservation \& Recycling, 130, 51-59, https://doi.org/10.1016/j.resconrec.2017.11.018.

Bhoite, R.N. and Murthy, P.S. (2015), "Biodegradation of coffee pulp tannin by Penicillium verrucosum for production of tannase, statistical optimization and its application”, Food Bioprod. Process, 94, 727-735, https://doi.org/10.1016/j.fbp.2014.10.007.

Brandelli, A. (2008), "Bacterial keratinases: useful enzymes for bioprocessing agroindustrial wastes and beyond", Food. Bioproc.Technol, 1, 105-116, https://doi.org/10.1007/s11947-007-0025-y.

Chen, L. and Neibling, H. (2014), Anaerobic digestion basics, University of Idaho, 1-6.

Chen, Y., Cheng, J.J. and Creamer, K.S. (2008), "Inhibition of anaerobic digestion process: a review", Bioresource Technology, 99, 4044-4064, https://doi.org/10.1016/j.biortech.2007.01.057.

Cirne, D.G., Lehtomaki, A., Bjornsson, L. and Blackall, L.L. (2007), "Hydrolysis and microbial community analyses in two-stage anaerobic digestion of energy crops", J. Appl. Microbiol., 103, 516-527, https://doi.org/10.1111/j.1365-2672.2006.03270.x.

Gerardi, M.H. (2003), The Microbiology of Anaerobic Digesters, Published by John Wiley\&Sons, Inc., Hoboken, New Jersey, ISBN 0-471-20693-8.

Gould, M.C. (2014), Bioenergy and anaerobic digestion in Bioenergy - Biomass to biofuels, edited by A Dahiya, Ed. Academic Press, ISBN 9780124081208.

Gupta, R. and Ramnani, P. (2006), "Microbial keratinases and their prospective applications: an overview", Appl. Microbiol. Biotechnol., 70, 21-33, https://doi.org/10.1007/s00253-005-0239-8.

Gurav, R.G. and Jadhav, J.P. (2013), "A novel source of biofertilizer from feather biomass for banana cultivation", Env. Sci. Pollut. Res, 20, 4532-4539, https://doi.org/10.1007/s11356-012-1405-z.

Hejnfelt, A. and Angelidaki, I. (2009), "Anaerobic digestion of slaughterhouse by-products", Biomass Bioenerg., 33, 1046-1054, https://doi.org/10.1016/j.biombioe.2009.03.004. 


\section{Biological Pretreatment of Waste from the Leather Industry to Obtain Biogas through Anaerobic Co-Digestion Processes - A Review}

John Sundar, V., Raghavrao, J., Muralidharan, C. and Mandal, A.B. (2011), "Recovery and utilization of chromium-tanned proteinous wastes of leather making: a review", Crit Rev Environ Sci Technol, 41, 2048-75, https://doi.org/10.1080/10643389.2010.497434.

Kalyanaraman, C., Kameswari, K.S.B. and Rao, J.R. (2015), "Studies on enhancing the biodegradation of tannins by ozonation and Fenton's oxidation process", J. Ind. Eng. Chem. 25, 329-337, https://doi.org/10.1016/j.jiec.2014.11.012.

Kalyuzhnyi, S., Veeken, A. and Hamelers, B. (2000), "Two - particle model of anaerobic solid - state fermentation", Water Science and Technology, 41, 43-50, https://doi.org/10.2166/wst.2000.0054.

Karlsson, A., Björn, A., Shakeri Yekta, S. and Svensson, B.H. (2014), "Improvement of the biogas production process. Explorative project (EP1)", Biogas Research Center, Linköping University, Sweden.

Katsifas, E.A., Giannoutsou, E., Lambraki, M., Barla, M. and Karagouni, A.D. (2004), "Chromium recycling of tannery waste through microbial fermentation", $J$ Ind Microbiol Biotechnol, 31, 57-62, https://doi.org/10.1007/s10295-004-0115-z.

Khalid, A., Arshad, M., Anjum, M., Mahmood, T. and Dawson, L. (2011), "The anaerobic digestion of solid organic waste", Waste Management, 31, 1737-1744, https://doi.org/10.1016/j.wasman.2011.03.021

Kreplak, L., Doucet, J., Dumas, P. and Briki, F. (2004), "New aspects of the $\alpha$-helix to $\beta$ - sheet transition in stretched hard $\alpha$ - keratin fibers", Biophys. J., 87, 640-647, https://doi.org/10.1529/biophysj.103.036749.

Kupec, J., Dvorackova, M., Rudolva, S., Rucika, J. and Kolemaznik, K. (2002), "Deproteination of chrome waste by washings and enzymatic hydrolysis", J Am Leather Chem Assoc, 97, 349-54.

Mannucci, A., Munz, G., Mori, G. and Lubello, C. (2010), "Anaerobic treatment of vegetable tannery wastewaters: a review", Desalination, 264, 1-8, https://doi.org/10.1016/j.desal.2010.07.021.

Mella, B., Glanert, A.C. and Gutterres, M. (2016), "Removal of chromium from tanning wastewater by chemical precipitation and electrocoagulation", J. Soc. Leather Technol. Chem., 100, 55-61

Nallathambi Gunaseelan, V. (1997), "Anaerobic digestion of biomass for methane production: a review", Biomass Bioenergy, 13, 83-114, https://doi.org/10.1016/S0961-9534(97)00020-2.

Parry, D.A.D. and North, A.C.T. (1998), "Hard keratin intermediate filament chains: substructure of the Nand C-terminal domains and the predicted structure and function of the C-terminal domains of type 1 and type 2 chains", J. Struct. Biol., 122, 67-75, https://doi.org/10.1006/jsbi.1998.3967.

Paul, T., Halder, S.K., Das, A., Bera, S., Maity, C., Mandal, A., Das, P.S., Mohapatra, P.K.D., Pati, B.R. and Mondal, K.C. (2013), "Exploitation of Chicken Feather Waste as a Plant Growth Promoting Agent Using Keratinase Producing Novel Isolate Paenibacillus woosongensis TKB2", Biocat. Agricul. Biotechnol., 2, 50-57, https://doi.org/10.1016/j.bcab.2012.10.001.

Paul, T., Jana, A., Mandal, A.K., Mandal, A., Das Mohpatra, P.K. and Mondal, K.C. (2016), "Bacterial keratinolytic protease, imminent starter for NextGen leather and detergent industries", Sustainable Chemistry and Pharmacy, 3, 8-22, https://doi.org/10.1016/j.scp.2016.01.001.

Paul, T., Mandal, A., Mandal, S.M., Ghosh, K., Mandal, A., Halder, S.K., Das, A., Maji, S.K., Kati, A., Das Mohapatra, P.K., Pati, B.R. and Mondal, K.C. (2015), "Enzymatic Hydrolyzed Feather Peptide, a Welcoming Drug for Multiple-Antibiotic-Resistant Staphylococcus aureus: Structural Analysis and Characterization", Appl. Biochem. Biotech., 175, 3371-3386, https://doi.org/10.1007/s12010-015-1509-2.

Piccin, J.S., Gomes, C.S., Mella, B. and Gutterres, M. (2016), "Color removal from real leather dyeing effluent using tannery waste as an adsorbent", J. Environ. Chem. Eng., 4, 1061-1067, https://doi.org/10.1016/j.jece.2016.01.010.

Pillai, P. and Archana, G. (2012), "A novel process for biodegradation and effective utilization of chrome shavings, a solid waste generated in tanneries, using chromium resistant Bacillus subtilis P13", Process Biochemistry, 47, 2116-2122, https://doi.org/10.1016/j.procbio.2012.07.030.

Scano, E.A., Asquer, C., Pistis, A., Ortu, L., Demontis, V. and Cocco, D. (2014), "Biogas from anaerobic digestion of fruit and vegetable wastes: Experimental results on pilot - scale and 7 preliminary performance evaluation of a full-scale power plant", Energy Conversion and Management, 77, 22-30 https://doi.org/10.1016/j.enconman.2013.09.004

Schnürer, A. and Jarvis, Å. (2010), "Microbiological handbook for biogas plants", Swedish Waste Management U2009:03 Swedish Gas Centre Report 207.

Thacker, U., Parikh, R., Shouche, Y. and Madamwar, D. (2006), "Hexavalent chromium reduction by Providencia sp.”, Process Biochem, 41, 1332-7, https://doi.org/10.1016/j.procbio.2006.01.006.

Valenti, G., Arcidiacono, A. and Nieto Ruiz, J.A. (2016), "Assessment of membrane plants for biogas upgrading to biomethane at zero methane emission", Biomass and Bioenergy, 85, 35-47, https://doi.org/10.1016/j.biombioe.2015.11.020.

Yi, Z., Jia, Z., Fuqing, X. and Yebo, L. (2014), "Pretratament of lignocellulosic biomass for enhanced biogas Review", Progress in Energy and Combustion Science, 42, 35-53, https://doi.org/10.1016/j.pecs.2014.01.001.

Zupancic, G.Z. and Grilc, V. (2012), "Anaerobic treatment and biogas production from organic waste", in: Management of organic waste, Edited by Kumar S. and Bharti A., InTech, ISBN 978-953-307-925-7. 